\title{
Internet Penetration and Regional Financial Development in China: Empirical Evidence Based on Chinese Provincial Panel Data
}

\author{
Qingquan Jiang $\left(\mathbb{D},{ }^{1}\right.$ Xiaosan Zhang $\mathbb{D}^{2},{ }^{2}$ Qiaozhen Lin $\left(\mathbb{D},{ }^{1}\right.$ Guofu Chen $\left(\mathbb{D},{ }^{3}\right.$ Rui Zhang $(\mathbb{D}){ }^{1}$ \\ and Songxian Liu ${ }^{1}$ \\ ${ }^{1}$ School of Economics \& Management, Xiamen University of Technology, Xiamen 361024, China \\ ${ }^{2}$ Research Centre for Belt \& Road Financial and Economic Development, Xiamen National Accounting Institute, Xiamen 361005, \\ China \\ ${ }^{3}$ School of Management, Xiamen University, Xiamen 361005, China
}

Correspondence should be addressed to Xiaosan Zhang; zxs@xnai.edu.cn, Guofu Chen; 1160848498@qq.com, and Rui Zhang; r.zhang@ymail.com

Received 12 March 2020; Revised 18 June 2020; Accepted 14 July 2020; Published 3 August 2020

Academic Editor: Chenxi Huang

Copyright (c) 2020 Qingquan Jiang et al. This is an open access article distributed under the Creative Commons Attribution License, which permits unrestricted use, distribution, and reproduction in any medium, provided the original work is properly cited.

\begin{abstract}
The Internet has revolutionized the patterns of financial development and economic growth. To assess the impacts of internet penetration on the financial industry, this paper analyzed ten-year Chinese provincial panel data and concluded that regional Internet penetration accelerates financial development. Furthermore, the efficiency of Internet investment in underdeveloped provinces is better than that in developed provinces. More meaningfully, Internet penetration promotes the transparency of the securities market and regional financial participation. This indicates that Internet technology facilitates the advancement of the finance industry and the securities market.
\end{abstract}

\section{Introduction}

The development of regional financial industry is affected by many factors, among which the level of regional economic development and the level of information technology are important to sustainable development of financial industry [1]. The influence of Internet on economy is various, from improving technical productivity to increasing foreign direct investment, from inflation to political and economic problems, and from corruption to democratic and free issues $[2,3]$.Governments of many developed and developing countries have recognized the huge growth potential of the Internet for their economy, and some countries have taken measures to greatly increase the construction of Internet infrastructure and increase the penetration rate of the Internet [4].

According to Moore's law (Moore), information technology represented by electronic information components and integrated circuits will continue to be updated [5]. Not only has the development of the Internet given birth to the development of a network economy, but also it has produced subversive changes in various industries [6]. In recent years, the extensive use of the Internet has produced a vast amount of data. Data are among the most useful tools in the Internet age. In fact, it has been noted that the Internet has entered the "Data Era" from the "Digital Era" [7]. Schumpeter pointed out that both endogenous R\&D (Research and Development) investment and external technological shocks are driving forces of economic development [8]. Lucas argued that the accumulation of technological innovation, material objects, and human capital is an important driving force for economic growth [9]. The development of Internet technology can directly drive the development of network economy, promote the change of information circulation and payment mode, stimulate the development of other industries, and indirectly drive the economic development of other industries. Internet applications in the financial sector have a long history [10]. From the statistics in 
Figures 1(a) and 1(b), it can be seen that, with the development of the network economy, financial services such as online payment and online banking have expanded to the Internet. However, the number of users and usage of online stocks have not gradually increased with the development of the Internet economy, indicating that the role of Internet in the development of the financial industry is different from that in traditional industry, and financial development under Internet environment has different qualities.

The Shanghai Stock Index (Figure 2) shows that since the emergence of the Internet in China in 1997, the proportion of online stocks reached 8\% according to the 1999 survey. The unprecedented development of the Internet economy around 2000 brought about a short "Bull Market" and led to the first increase in online stocks. The collapse of the Internet bubble brought about a "Bear Market" for several years; at the same time, the proportion of online stocks' users fell. Subsequently, between 2005 and 2008, the proportion of online stocks' users and the Shanghai Stock Index had the same trend. In particular, around 2007, nearly one-fifth of the web APPs were online stocks. In general, the securities market is closely related to the development of the Internet. Therefore, the Internet has become an important factor affecting the development of the financial industry.

Scholars believe that financial intermediation has a positive relationship with economic growth [11], and the development of stock market has also been causally linked to economic growth [12]. However, from the perspective of financial development, the driving force comes from two aspects: one is the stimulation of the financial industry by economic development and the second is the internal innovations of the financial industry itself. However, whether it is economic development or innovation in financial instruments, this movement requires the conditions essential for scientific and technological progress. Not only does the Internet provide a new tool for the development of the financial industry, but also it provides a fast and convenient platform for financial innovation.

On the one hand, the Internet increases the efficiency of the financial industry, which, in turn, has stimulated economic growth. Studies have confirmed that information and communication technologies have a stimulating effect on economic growth, and telecommunications infrastructure has an impact on regional economic growth $[13,14]$. Levine believes that a well-established financial business can improve information asymmetry, as well as identifying and investing in the most competitive and innovative companies and industries, thereby improving capital allocation efficiency [15]. The Internet can transmit information quickly and conveniently, which can greatly improve the asymmetry of information. For example, high-frequency transactions in the securities market require real-time information. The famous US network provider Spread Networks spent two years setting up the most direct fiber optic cable route possible between New York and Chicago, with a network round-trip speed 3 millisecond faster than the original [16]; therefore, many high-frequency traders have become its customers.
On the other hand, the development of the Internet and financial technology has provided a powerful platform for financial innovation, thus leading to "Internet finance" [17]. Hou et al. consider Internet finance an integration of Internet technologies and financial activities, playing an important role in payment and settlement, resource allocation, risk management, and networking channels [18]. Chang and Deng have argued that Internet financing is an advanced financial service that covers not only e-payment and e-banking, but also credit, guarantees, assurances, pledges, and collateralization [19]. Wang et al. define Internet finance as an emerging financial model that implements fund accommodation, payment, and infomediary services [20]. Therefore, the Internet plays a major role in promoting the innovations and development of the financial industry.

The structure of this paper is as follows: section 2 is literature review and proposes research hypotheses thereafter; section 3 mainly introduces the selection of indicators and data sources; section 4 conducts empirical analysis to verify the correlation between Internet development and regional financial development, financial development structure, and financial participation of investors; and section 5 is conclusions and recommendations with slight limitations and prospects of this research.

\section{Literature Review}

2.1. Internet Development Level and Regional Financial Development Level. Financial development is influenced by certain economic factors [21]. In the theory of exogenous economic growth, the Solow-Swan growth model identifies the role of technological growth in economic growth [22]. The development of the Internet belongs to both the infrastructure of economic development and the scope of technological progress. Internet infrastructure is closely connected to the economy [23] because ICT affects growth through fostering technology diffusion and innovation, enhancing the quality of decision-making by firms, increasing demand, and reducing production costs. Therefore, $\mathrm{Vu}$ argued that ICT is a source of economic growth [24]. Pradhan et al. concluded that ICT's role in GDP growth has been confirmed [25]; in addition, Binuyo and Aregbeshola explained the effect of ICT investment on the economy [26]. Tranos Granger tested the causality between the Internet infrastructure and the economic development of European city regions, with the results showing that ICT infrastructure is a necessary condition for economic development [27]. Pradhan et al. found that an embellishment of ICT infrastructure improved economic development in the form of per capital GDP in G20 countries [28]. Pradhan et al. confirmed that ICT infrastructure determines long-term economic growth in most Asian countries [28]. Using the statistical data of 1996-2007, Czernich et al. used an instrumental variable model and proved that when the broadband penetration rate increases by $10 \%$, it contributes to a $0.9-1.5 \%$ gain in economic growth in OECD countries [29].

Chinese ICT is developing rapidly in the 21 st century. One study indicated that the Chinese ICT infrastructure 


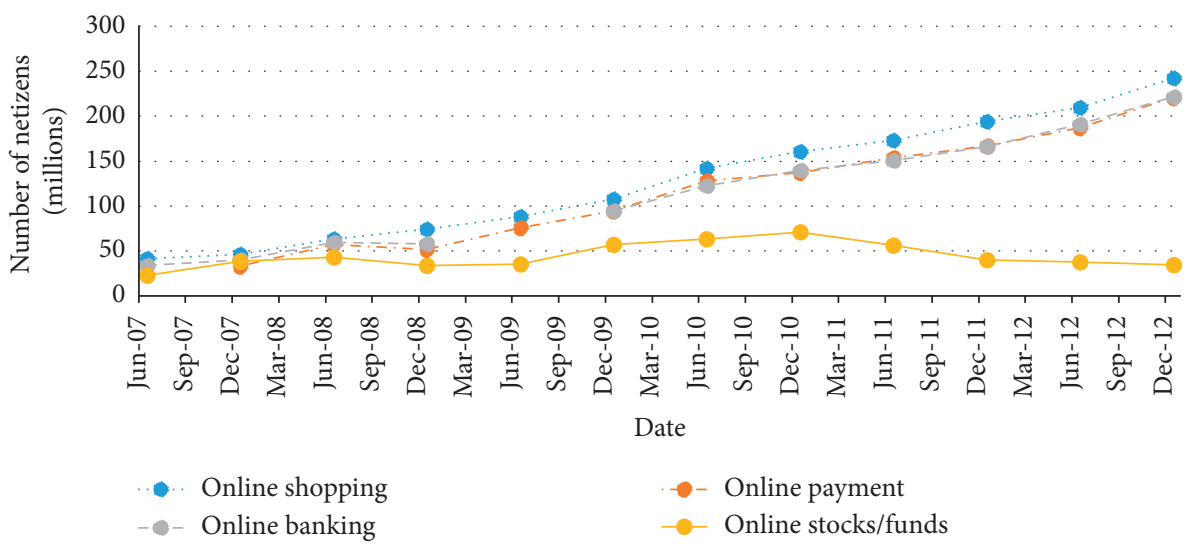

(a)

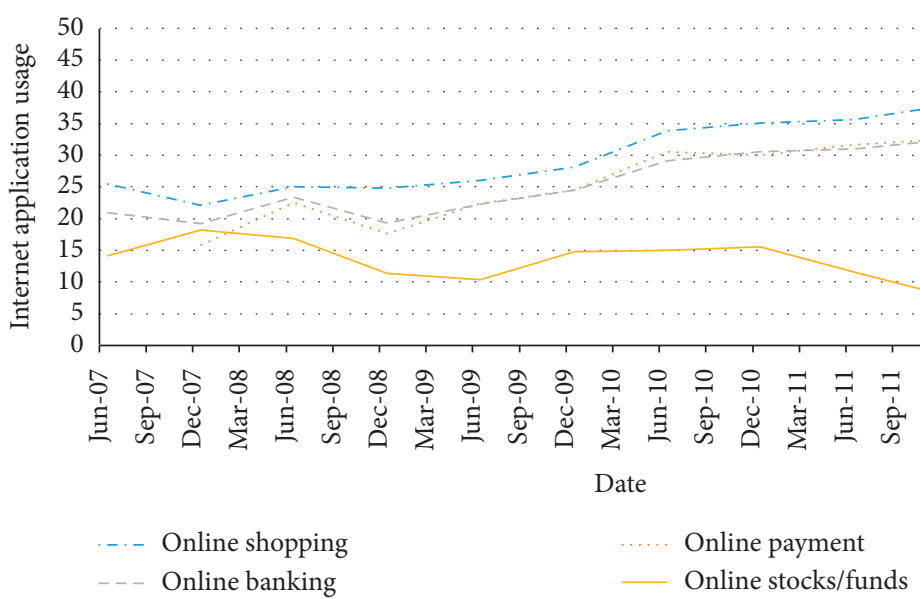

(b)

Figure 1: Statistics of Internet applications from 2007 to 2012 (data source: CNNIC China Internet Network Information Center).

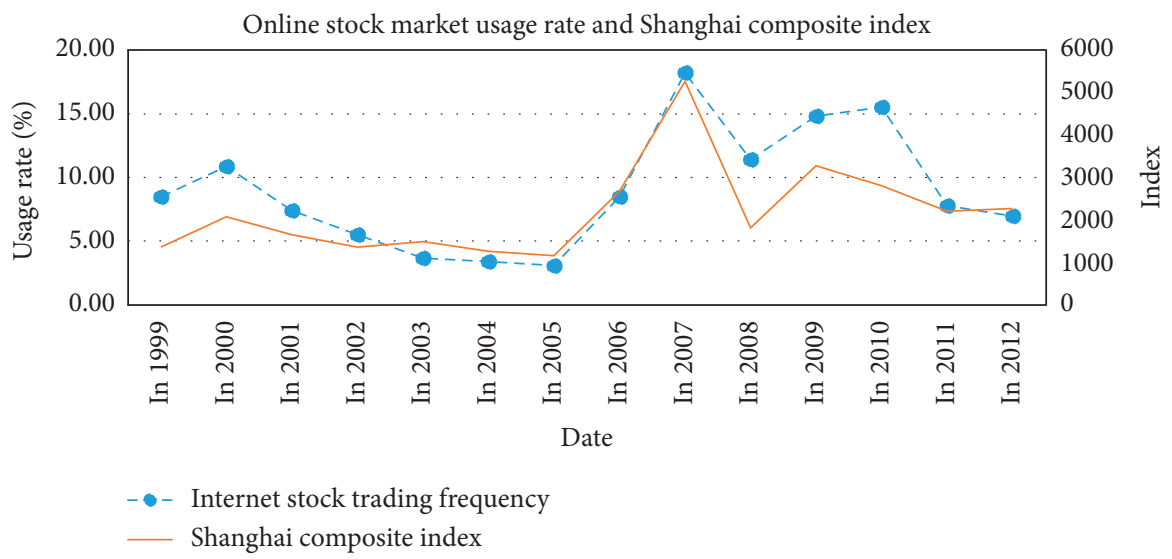

FiguRE 2: Online stock usage proportion and Shanghai Stock Index from 1999 to 2012 (data source: CNNIC China Internet Network Information Center and Wind database).

contribution rate has far exceeded that of the United States, Japan, and Germany since 2000. The results of Heshmati and Yang's research suggest that China has reaped the benefits of ICT investment [30]. Liu and $\mathrm{Hu}$ studied the spillover effects of transportation, energy, and information infrastructure on Chinese economic growth. The results show that transportation infrastructure and information infrastructure have a significant spillover effect on Chinese economic growth [31]. Regarding the promotion of technological progress, $\mathrm{Li}$ and Jing believe that the increase in the Internet penetration rate has different promoting effects on regional economic growth, and this stimulating effect reaches its 
maximum after five years [32]. Luo et al. found that the marginal contribution of Chinese telecom investment to Chinese economic growth averaged $2.376 \%$, which was $6.758 \%$ higher than other social infrastructure investments [33]. Zhong et al. concluded that a $10 \%$ increase in broadband penetration will boost the national economy by $0.444 \%$ [34]. Sharon [35] found that the Internet as a distribution medium was regarded by many enterprises as a legitimate way to reduce operating costs, and people were increasingly confident in using the Internet as a medium for transactions. Therefore, the author believes that the development of regional economy has promoted the development and penetration rate of the Internet to some extent, and the development of the Internet will further promote the improvement of financial development level. Based on the above analysis, this paper proposes the following hypotheses.

Hypothesis 1. Internet penetration promotes the development level of regional finance. That is, the higher the Internet penetration, the higher the level of regional financial development.

\subsection{Internet Development Level and Financial Participation of} Regional Investors. Lack of regional infrastructure construction may hinder the transmission of information, while afterwards information transmission or low efficiency may reduce people's understanding of things and decisionmaking ability. The development of Internet technology can speed up information transmission and alleviate various problems caused by information asymmetry, such as policy changes and financial investment. A few studies have argued that social interaction and trust promote the participation of citizens in the stock market [36-38]. The general investment losses caused by the stock market downturn will reduce the positive effect of social interaction, and the positive impact of social interaction on the participation of low-education residents in the stock market is more obvious [28]. Wang and Tian found that, in addition to the impact of economic development level and other factors on stock market participation, Chinese investors participation in the stock market will also change with that of financial market environment [39].

The popularization of the Internet enables the spread of scattered and asymmetric information and accelerates the utilization rate of information. According to the growth of modern endogenous theory, the Internet can promote the development of the industry by promoting the level of science and technology, big data analysis, information network circulation, and so on [40]. The spread of the Internet may affect the innovation capacity of the economy through the creation of knowledge spillover and the development of new products, new processes, and new business models to promote growth. The ease of access and dissemination of information facilitate the creation of new ideas and technologies [41]. The extensive use of the Internet fundamentally changes and improves the Internet information processing, leading to a significant increase in the productivity of companies using information technology
[42]. The Internet makes it possible to exchange data across multiple locations and helps decentralize information processing. It may also help the emergence of new business enterprise cooperation model relying on the spatial exchange of a large amount of information which promotes the development of enterprise competition and innovation process. The Internet is likely to increase market transparency, thus enhancing competition and promoting industry reform and development [43]. Noh and Yoo analyzed the relationship between Internet usage rate, income inequality, and economic growth, concluding that for countries with high income inequality, Internet usage has a negative impact on economic growth [44].

The difference in stock market participation is caused by information asymmetry [45]. The popularity of the Internet provides investors with a broad information platform, thus greatly reducing the cost of financial information dissemination, so the Internet enables investment in financial activities to respond to market changes in a timely manner [46]. Another purpose of this research is to study the impact of Internet popularization on willingness to participate in the stock market. Therefore, this research believes that the development of the Internet will further affect the transmission and circulation of information. The cost and time for investors to obtain information will be reduced, and they can learn more reliable information in a timely manner, which will reduce financial participation to some extent and avoid blind investment. Based on the above analysis, this paper proposes the following hypothesis.

Hypothesis 2. Internet penetration inhibits the financial participation of regional investors. That is, the higher the Internet penetration, the smaller the participation of investors in finance.

Through the analysis of literature review, it can tell that the development and popularization of the Internet have greatly improved the flow and acquisition of information and numbers. As an important industry to measure the level of economic development, the level of financial development and the business of all financial industry are affected [47]. In addition, the improvement of information acquisition cost and efficiency alleviates the information asymmetry, and many investors will have a better understanding of the specific information of financial investment and make decisions [48], which may create new challenges for the development of the financial industry. Therefore, the research on the influence of Internet popularization and development level on the development of the financial industry and the influence of investors' financial participation can explore these issues.

There are different ways of selecting indicators for Internet penetration and financial development. Some scholars choose Telecommunications usage, such as telephone usage, for example, telephone penetration rate to measure the development of science and technology level and information flows, but these indicators can only measure part of the information infrastructure. The network port number, optical fiber length, and other data are not of the most direct practical significance to users due to regional and technical 
differences, because the development of the Internet requires not only the investment of hardware equipment, but also the investment of technology. Later, the study of this paper also confirmed that although the information infrastructure investment in the region sent by the economy is more, the penetration rate is relatively high, but the efficiency of investment is low. Therefore, this paper updated the measurement indicators more comprehensively measuring the level of Internet development and financial development and further verified it through the robustness test.

\section{Methodology}

\subsection{Variable Selection}

3.1.1. Internet Development Level. The level of Internet development is mainly measured from two aspects. The first aspect is the investment in Internet infrastructure. Because investment in the Internet involves hardware and software in various fields such as telecommunications infrastructure, information transmission, the software industry, and digital products, the data are complicated, and this paper uses the capital stock of information transmission, computer service, and software industry fixed assets investment of China as substitute variables for Internet infrastructure investment, including industry infrastructure investment, technology investment, and asset investment. The second aspect is Internet popularization, including the Internet penetration rate, proportion of netizens, and number of netizens. The Internet penetration rate is calculated from the ratio of the number of netizens to the population of the region. The number of netizens is calculated based on the number of Internet users in the China Internet Network Information Center (CNNIC). The local population is based on the census data or the results of calculations published by the National Bureau of Statistics for that particular year.

The methods for estimating the capital stock of fixed assets investment in information transmission, computer services, and the software industry are as follows: first, this paper estimates the total fixed capital stock of the whole society by using the data of fixed assets investment of the whole society from 1985 to 2002. Second, based on the average ratio of fixed assets investment in information transmission, computer services, and the software industry from 2003 to 2006, the ratio data of information transmission, computer service, and software industry from 1985 to 2002 is collected. Finally, based on the perpetual inventory method (PIM), for estimating the capital stock of 2003, 2003 is made the base year and used for estimating capital stock from 2003 to 2012; the equation is as follows:

$$
K_{i t}=K_{i t-1}(1-\varepsilon)+I_{i t} .
$$

This paper adopted the methods of Zhang et al. [49] and Jin [50]. 10\% of the earliest investment as the capital stock of the base period is used, and the base period (1985) is the constant price, as shown in the following equation:

$$
K_{i}=\frac{I_{i+1}}{g+\varepsilon},
$$

where $K$ is the capital stock, $I$ is the investment amount, $\varepsilon$ is the depreciation rate, and $g$ is the average growth rate during the observation period. This paper assumes that the depreciation rate of infrastructure investment in each region is equal. According to the calculation results of Jin [50], the depreciation rate of Chinese infrastructure is $9.2 \%$. The ratio of the local investment amount to the national investment amount is applied as the weight to estimate the region's capital stock for the base year (2003). The calculation method is as follows:

$$
K_{i, 2003}=\frac{I_{i, 2003}}{\sum I_{i, 2003}} \cdot K_{2003} .
$$

3.1.2. Financial Development Level. This paper uses two indicators to measure the level of regional financial development. First, in order to fully reflect the level of financial development, referring to Goldsmith [51], this paper uses the ratio of the contribution of the financial industry's production value to the GDP of each province as the financial development level indicator and adopts the per capital financial industry production value as another measure. Second, according to the research of King and Levine [52], the financial development indicators are refined and extended to the insurance and banking industries. In order to better measure the financial development structure of each region, this paper takes the local stock market value as a substitute variable for the securities market. In summary, this paper uses the insurance industry income, the year-end bank loan amount, and the stock market value as the main indicators of the financial development structure of the region.

(1) Regional Economic Development Level. Referring to the index system of economic growth created by King and Levine (1993), this paper uses per capital GDP as the main variable of the regional economic development level. Similarly, per capital consumption was used as an indicator of household consumption level.

(2) Residents' Income Level. This paper introduced the disposable income of residents as the control variable of the per capital disposable income of residents. The relevant literature suggests that property holdings may also be a significant factor in financial participation [53]. Therefore, this article introduces per capital property holdings as an alternative variable to residents' current disposable income.

(3) Education Level. The popularity of the Internet is related to the education level in each region. In this paper, sample survey data of the popularization rate of junior high school education, high school education, and college education in each province as the education level index of each region is applied. Using the years of education as the weight, weighted average is applied and the average level of education in the 
area is obtained. The junior high school education is three years, so the weight is 3 ; high school is 6 ; and junior college is 10 .

(4) Investor Participation in the Stock Market. This article uses the number of per capital accounts opened in each year as an indicator of stock market participation; in addition, (Financial Industry Output Value/Per Capita Disposable Income), (Securities Transaction Amount/Per capita Disposable Income), and (Stock Trading Volume/Per capita Disposable Income) were used as indicators of financial participation intention, indicating the financial production value of the per capital disposable income contribution and the per capital disposable income controlling the volume of securities and stocks traded.

3.2. Data Sources. On April 20, 1994, China was connected to the Internet through a $64 \mathrm{~K}$ international special line, and the Chinese Internet was born. The development of Internet in China has experienced three major waves: the first Internet wave (1994-2000), the second Internet wave (2001-2008), and the third Internet wave (2009-2014). Based on the development of Internet in China, this study chooses 10 years as the research period to analyze the relationship among Internet development, financial development, and regional investors. As the largest developing country, China has made remarkable progress in science, technology, and economic development. Therefore, it is valuable to study the relationship between Internet and economic development in China. The data adopted in this study are samples from more than 30 regions in China. Due to the imbalance of economic development level in various regions in China, the Internet development and economic development in different regions have their own characteristics. Therefore, the research on more than 30 regions in China can also help to understand the role of Internet technology level towards economic development in different regions.

The data on Internet penetration rate, proportion of netizens, number of netizens, and so forth mainly come from the China Internet Network Information Center (CNNIC); network speed data mainly come from the speed report released by 360 companies and broadband network alliances. Information industry investment data come from the China Statistical Yearbook and the official website of the National Bureau of Statistics. Macro data such as per capital GDP, education level, and financial industry data come from the national data website published by the National Bureau of Statistics. For property holdings, due to a lack of accurate, relevant data, this paper mainly used the annual data of residential sales across the country, as well as the data from the straight flush iFinD collected from the China Statistical Yearbook. Bank deposits, bank loans, and premium income come from the China Statistical Yearbook and the China Financial Statistics Yearbook; securities trading volume, stock trading quotas, and stock account opening data are from the Wind database and the China Securities and Futures Statistical
Yearbook. Descriptive statistics for the main variables are shown in Table 1.

\section{Empirical Test Results and Discussion}

4.1. Internet Development Level and Regional Financial Development Level. In order to examine the impact of Internet development on regional financial development, the impact of Internet development levels on the overall level of regional financial development is examined. This paper represents the overall development level of regional finance using the financial industry GDP ratio and per capital financial production value. It expresses the development level of the Internet by the two indicators of capital transmission and the Internet penetration rate of information transmission, computer service, and software industry fixed assets investment in various regions. The capital stock represents the investment in the Internet in various regions, and the penetration rate indicates the output of the Internet in various regions. Based on the basic Cobb-Douglas model, the relationship between the capital stock of fixed asset investment and the Internet penetration rate of information transmission, computer service, and software industry in each region is estimated by constructing a basic CobbDouglas production function [53], as shown in the following formula:

$$
\text { Networks }=\mathrm{A} \times \text { Employment }^{\alpha} \times \text { Investment }^{1-\alpha} .
$$

A logarithm formula (equation (4)) can be obtained:

$$
\begin{aligned}
\operatorname{Ln}(\text { Networks })= & \ln \mathrm{A}+\ln (\text { employment })^{\alpha} \\
& +\ln (\text { Investment })^{1-\alpha},
\end{aligned}
$$

where Networks is the Internet penetration rate that year, Employment represents the number of employees, and Investment represents the capital stock of fixed assets investment in information transmission, computer service, and software industry in various regions.

Table 2 shows the estimated capital stocks of fixed asset investment in information transmission, computer services, and software industries in various regions of China. In Table 3 (panel A and panel B), the capital stock data in Table 2 is applied. The capital stock of fixed asset investment in information transmission, computer service, and software industry in each region is used as the capital investment for Internet development to test whether it has the same effect as the level of Internet popularization. Table 4 shows the impact of network popularity on financial development. In addition, the analysis of the individual fixed effect model in equation (1) found that the analysis results are not significant, and there is no time lag effect on the penetration rate of the Internet and the production value of the financial industry. Therefore, the subsequent analysis in this paper uses the current period data.

In terms of analysis methods, fixed effects model, random effects model, and mixed effects model are applied accordingly conducting the Hausman test. If the zero hypothesis is rejected, the fixed effect can be used; otherwise, if the zero hypothesis is accepted, the random effect can be 
TABLE 1: Descriptive statistics of the main variables (2003-2012)

\begin{tabular}{|c|c|c|c|c|c|}
\hline Parameter & $\begin{array}{c}\text { Number of } \\
\text { observations }\end{array}$ & $\begin{array}{l}\text { Minimum } \\
\text { value }\end{array}$ & $\begin{array}{l}\text { Maximum } \\
\text { value }\end{array}$ & Mean & $\begin{array}{l}\text { Standard } \\
\text { deviation }\end{array}$ \\
\hline Internet penetration & 300 & 0.02 & 0.68 & 0.20 & 0.15 \\
\hline Internet penetration in neighboring provinces & 300 & 0.04 & 0.56 & 0.21 & 0.13 \\
\hline Information industry capital stock (100 million) & 300 & 182.87 & $75,122.72$ & $11,402.80$ & $11,014.09$ \\
\hline Education level (\% junior middle school) & 300 & 0.02 & 0.05 & 0.04 & 0.01 \\
\hline Education level (\% senior high school) & 300 & 0.00 & 0.03 & 0.01 & 0.00 \\
\hline Education level (\% technical secondary school) & 300 & 0.00 & 0.03 & 0.01 & 0.01 \\
\hline Stock market value (million) & 300 & 75.84 & $204,030.20$ & 6022.71 & $18,825.92$ \\
\hline $\begin{array}{l}\text { Bank deposit (year-end balance, } 100 \text { million yuan } \\
\text { RMB RMB) }\end{array}$ & 300 & 544.36 & $91,589.51$ & $14,986.14$ & $15,588.60$ \\
\hline $\begin{array}{l}\text { Bank loan (year-end balance, } 100 \text { million yuan } \\
\text { RMB RMB) }\end{array}$ & 300 & 566.98 & $58,611.22$ & $10,371.00$ & $10,427.83$ \\
\hline $\begin{array}{l}\text { Premium income (year-end balance, } 100 \text { million } \\
\text { yuan RMB RMB) }\end{array}$ & 300 & 7.37 & 1593.25 & 283.21 & 277.39 \\
\hline Securities transaction volume (millions) & 300 & 84.02 & 255.09 & 226.96 & 411.01 \\
\hline Stock trading volume (millions) & 300 & 5.98 & 1680.54 & 171.21 & 305.52 \\
\hline GDP per capital (yuan RMB) & 300 & 3257.00 & $76,074.00$ & $20,575.31$ & $14,754.56$ \\
\hline Consumption level (yuan RMB) & 300 & 2502.00 & $35,439.00$ & 8097.25 & 5238.15 \\
\hline Per capital disposable income (yuan RMB) & 300 & 6530.48 & $36,230.48$ & $13,638.90$ & 5579.27 \\
\hline Proportion of finances in GDP & 300 & 0.01 & 0.13 & 0.03 & 0.02 \\
\hline Securities account opening ratio (\%) & 240 & 0.29 & 15.85 & 3.15 & 3.19 \\
\hline Property holding level & 240 & 9956.00 & $795,823.00$ & $171,652.00$ & $20,447.47$ \\
\hline
\end{tabular}

TABLE 2: Capital stock of fixed assets investment in information transmission, computer service, and the software industry in various regions of China.

\begin{tabular}{|c|c|c|c|c|c|c|c|c|c|c|}
\hline District & 2003 & 2004 & 2005 & 2006 & 2007 & 2008 & 2009 & 2010 & 2011 & 2012 \\
\hline Beijing & 4241.69 & 538.63 & 6734.19 & 670.15 & $10,861.47$ & $12,228.68$ & $17,777.49$ & $24,146.84$ & $25,044.59$ & $34,136.06$ \\
\hline Tianjin & & & & 386 & & & & & & \\
\hline Hebei & 3300.41 & 4177.80 & 5722.15 & 216.52 & 6709.46 & 11390.51 & 1571.11 & 6942.43 & $17,438.89$ & $18,716.24$ \\
\hline Shanxi & 1747.39 & 06.41 & 2609.04 & 52.36 & 5299.97 & 8135.65 & $11,186.47$ & 7026.68 & 5762.84 & 7505.47 \\
\hline nner Mongolia & 979.27 & 1275.02 & 1401.46 & 1748.46 & 6264.04 & 4296.40 & 6076.08 & $10,144.03$ & $15,607.37$ & $17,525.40$ \\
\hline iaoning & 2834.21 & & & & 7976.93 & $13,819.78$ & $16,831.64$ & $24,686.06$ & 23,38 & 9.61 \\
\hline Jilin & 688 & & 203 & 3602 & 4680 & 5421.52 & 7242 & & 844 & $14,692.67$ \\
\hline Teilongjiang & 376 & & 721 & & 14,9 & 18,74 & & & & \\
\hline hanghai & 3774.01 & 343 & 5421.24 & $11,161.60$ & 12,34 & $13,495.30$ & & & & \\
\hline angsu & 4407.45 & 4139 & 6760.51 & 749 & 598 & 7700 & 18,7 & 28 & 40 , & 56 \\
\hline Zhe & 4 & & & & $13, \mathrm{c}$ & 16,06 & 20,3 & & & \\
\hline & & & & & & & & & & \\
\hline Fujian & 301 & 484 & 568 & & 67 & $15,326.05$ & 18 & 23,8 & .09 & 30 , \\
\hline Rn: & 2665.98 & 4101.32 & 555 & 470 & 706 & 3863 & 61 & 11,1 & & 10,6 \\
\hline Sha & 4 & & & 3 & & 45 & & & 67 & \\
\hline & & & & & & & & & & \\
\hline & 274 & 45 & 414 & & & 747 & & 12 & .04 & 0.40 \\
\hline Hunan & 2029.09 & 2818 & 4436 & 522 & 720 & $10,330.80$ & 13,3 & 18,7 & 16 & $12,566.02$ \\
\hline Guangdon & $12,721.63$ & 17,52 & 12 & & 23,5 & 28,58 & & 42 , & & $71,977.44$ \\
\hline $\mathrm{Gu}$ & & & & & & & & & & \\
\hline $\mathrm{Ha}$ & 2 & 4 & 21 & 5 & 1 & 191 & 24 & 0 & 64 & 7360.04 \\
\hline Sichuan & 5521.90 & 7945.98 & & 9718.24 & $11,486.24$ & $18,109.42$ & $24,972.60$ & $31,763.29$ & $28,310.04$ & $30,964.00$ \\
\hline Guizhou & & & & & & & & & & \\
\hline Yunna & & & & & & & & & & 12 \\
\hline Tibet & 341.88 & 441.23 & 1041.42 & 944.75 & 37 & 1181.19 & 122 & 1870.41 & 1321.71 & 2685.19 \\
\hline Shang & 1601.37 & 2845.89 & 3987.46 & 4264.07 & 7675.92 & 5199.23 & 7470.50 & $13,379.34$ & $13,894.75$ & $18,193.54$ \\
\hline Gansu & 87024 & 34.95 & 1361.19 & 1721.37 & 2009.78 & 1777.45 & 2482.08 & 3892.48 & 7205.24 & 6780.42 \\
\hline Qinghai & 251.11 & & & 376.99 & & 357.52 & & 421.26 & 131.33 & 411.00 \\
\hline Ningxia & 369.01 & 549.96 & 637.14 & 533.21 & 642.11 & 928.45 & 1662.70 & 2611.84 & 3615.04 & 2417.51 \\
\hline Xinjiang & 2499.23 & 2294.66 & 3378.36 & 3472.63 & 4615.17 & 6283.54 & 5842.63 & 7077.23 & $10,559.14$ & 9242.20 \\
\hline
\end{tabular}

Note. Since Chongqing became a municipality in 1997, during most of the estimated period (1985-2002), Chongqing is attributed to Sichuan. Therefore, this paper follows the historical economic data and attributes Chongqing to Sichuan. 
TABLE 3: Investment in Internet infrastructure and regional financial development level. Panel A: financial industry/GDP share and capital investment in Internet infrastructure. Panel B: per capital financial output and capital investment in Internet infrastructure.

\begin{tabular}{|c|c|c|c|c|}
\hline & \multicolumn{2}{|c|}{ Mixed OLS model } & \multicolumn{2}{|c|}{ Regional fixed effect model } \\
\hline & 1 & 2 & 3 & 4 \\
\hline \multicolumn{5}{|l|}{ Financial industry/GDP } \\
\hline \multirow{2}{*}{ Intercept } & -0.1746 & $-0.0846^{* *}$ & $-0.1231^{* * *}$ & $-0.1587^{* * *}$ \\
\hline & 0.0427 & 0.0366 & 0.0426 & 0.0327 \\
\hline \multirow{2}{*}{ Infrastructure capital stock } & $-0.0052^{* * *}$ & $-0.0026^{* * *}$ & $0.0021^{*}$ & $0.0021^{* *}$ \\
\hline & 0.0011 & 0.001 & 0.0012 & 0.0012 \\
\hline \multirow{2}{*}{ Education level (average) } & $0.0206^{* * *}$ & - & 0.009 & - \\
\hline & 0.0069 & & 0.0057 & \\
\hline \multirow{2}{*}{ Education level (above college) } & - & $0.0243^{* * *}$ & - & 0.002 \\
\hline & & 0.0031 & & 0.0022 \\
\hline \multirow{2}{*}{ Per capital GDP } & $-0.0411^{* * *}$ & $-0.0439^{* * *}$ & $-0.0337^{* * *}$ & $-0.0338^{* * *}$ \\
\hline & 0.0059 & 0.0052 & 0.0061 & 0.0061 \\
\hline \multirow{2}{*}{ Resident per capital disposable income } & 0.0144 & 0.0242 & $0.0354^{* * *}$ & $0.0344^{* * *}$ \\
\hline & 0.0099 & 0.0079 & 0.0107 & 0.0107 \\
\hline \multirow{2}{*}{ Household consumption level } & $0.0689^{* * *}$ & $0.0525^{* * *}$ & $0.0212^{* *}$ & $0.023^{* *}$ \\
\hline & 0.0091 & 0.0084 & 0.0095 & 0.0095 \\
\hline$R^{2}$ & 0.6407 & 0.7077 & 0.9568 & 0.9564 \\
\hline Observations & 270 & 270 & 270 & 270 \\
\hline \multicolumn{5}{|l|}{ Per capital financial output } \\
\hline \multirow{2}{*}{ Intercept } & -0.9098 & 0.6033 & $-9.3739^{* * *}$ & $-8.8804^{* * *}$ \\
\hline & 1.6503 & 1.442 & 2.0835 & 1.5919 \\
\hline \multirow{2}{*}{ Infrastructure capital stock } & $-0.3889^{* * *}$ & $-0.2675^{* * *}$ & $0.0973^{*}$ & $0.0972^{*}$ \\
\hline & 0.0431 & 0.0413 & 0.0567 & 0.0567 \\
\hline \multirow{2}{*}{ Education level (average) } & $1.6017^{* * *}$ & - & 0.0142 & \\
\hline & 0.2669 & & 0.279 & \\
\hline \multirow{2}{*}{ Education level (above college) } & - & $1.1114^{* * *}$ & - & 0.0593 \\
\hline & & 0.1206 & & 0.109 \\
\hline \multirow{2}{*}{ Per capital GDP } & $-1.0909^{* * *}$ & $-0.9737^{* * *}$ & $-1.256^{* * *}$ & $-1.2413^{* * *}$ \\
\hline & 0.2282 & 0.1952 & 0.2973 & 0.2978 \\
\hline \multirow{2}{*}{ Resident per capital disposable income } & 0.6008 & 0.4868 & $2.8266^{* * *}$ & $2.8169^{* * *}$ \\
\hline & 0.3824 & 0.3127 & 0.5228 & 0.5222 \\
\hline \multirow{2}{*}{ Household consumption level } & $1.8868^{* * *}$ & $1.4386^{* * *}$ & -0.6482 & -0.6824 \\
\hline & 0.3521 & 0.3292 & 0.466 & 0.4609 \\
\hline$R^{2}$ & 0.6546 & 0.7090 & 0.9336 & 0.9337 \\
\hline Observations & 270 & 270 & 270 & 270 \\
\hline
\end{tabular}

Note. $(1){ }^{*}, * *$, and ${ }^{* * *}$ represent significance at the levels of $10 \%, 5 \%$, and $1 \%$, respectively; (2) the standard error is presented below the coefficient.

used. But this approach often backfires. Another method is to determine which model to use according to the nature of the data before establishing the model. For example, data are sampled from the population, and random effects can be used. If the data are aggregate data, such as GDP of 31 provinces and cities, there is no random sampling problem, so fixed effect is used. The choice between fixed effect model and mixed effect model is to regress the fixed effect model first, and then carry out the likelihood ratio test. If the test result is significant, it belongs to fixed effect model; otherwise, it belongs to mixed effect model. In this study, panel data of 31 provinces and cities in China are used, so fixed effect can be used for analysis. At the same time, in order to test data more comprehensively, fixed effect model and mixed effect model are chosen for comparison, to analyze the effect of Internet technology in different regions towards economic development.

Panel A of Table 4 indicates that the mixed OLS estimates indicate that the Internet penetration rate is strongly correlated with the financial industry GDP under the control of other factors, and the impact of educational level and the financial industry is positive; however, the results of the analysis after the regional fixed effects show that the level of education is not significant and is negative, indicating that the relationship between the development of local finances and the level of education is not significant, and the level of education has a weak correlation with local financial development. Panel B (per capital financial industry output) shows that the mixed OLS model indicates that the Internet penetration rate has a certain relationship with the per capital financial output value. Hypothesis 1 is correct. Similarly, the coefficient of the junior high school education level of 0.3850 relative to the high school education level is 1.1976 , indicating that the role of per capital financial output will also become more pronounced with an improvement in the education level. From the panel regression analysis of regional fixed effects, it can be seen that the penetration rate of the Internet in each region has a positive impact on the per capital financial output. In addition, although Tan believes that the development of financial intermediation is strong 
TABLE 4: Internet development level and regional financial development level. Panel A: financial industry/GDP ratio and Internet development level. Panel B: per capital financial output and Internet development level.

\begin{tabular}{|c|c|c|c|c|c|c|}
\hline \multirow{3}{*}{ Financial industry/GDP (panel A) } & \multicolumn{3}{|c|}{ Mixed OLS model } & \multicolumn{3}{|c|}{ Regional fixed effect model } \\
\hline & 1 & 2 & 3 & 4 & 5 & 6 \\
\hline & & & & & & \\
\hline Intercept & $\begin{array}{l}0.0583 \\
0.0421\end{array}$ & $\begin{array}{c}0.0821^{* *} \\
0.0334\end{array}$ & $\begin{array}{l}0.0066 \\
0.0395\end{array}$ & $\begin{array}{c}-0.1116^{* *} \\
0.0456\end{array}$ & $\begin{array}{c}-0.1181^{* * *} \\
0.0348\end{array}$ & $\begin{array}{l}-0.1204^{* * *} \\
0.0370\end{array}$ \\
\hline Internet penetration rate & $\begin{array}{l}0.0708^{* * *} \\
0.0092\end{array}$ & $\begin{array}{l}0.0346^{* * *} \\
0.0091\end{array}$ & $\begin{array}{l}0.0811^{* * *} \\
0.0084\end{array}$ & $\begin{array}{l}0.0305^{* * *} \\
0.0073\end{array}$ & $\begin{array}{c}0.0332^{* * *} \\
0.0074\end{array}$ & $\begin{array}{l}0.0304^{* * *} \\
0.0070\end{array}$ \\
\hline Education level (average) & $\begin{array}{c}0.0119^{*} \\
0.0069\end{array}$ & - & - & $\begin{array}{c}-0.0030 \\
0.0064\end{array}$ & - & - \\
\hline Education level (above college) & - & $\begin{array}{c}0.0241^{* * *} \\
0.0031\end{array}$ & - & - & $\begin{array}{c}-0.0036 \\
0.0023\end{array}$ & - \\
\hline Education level (high school or above) & - & - & $\begin{array}{c}-0.0053 \\
0.0051\end{array}$ & - & - & $\begin{array}{c}-0.0055 \\
0.0043\end{array}$ \\
\hline Per capital GDP & $\begin{array}{c}-0.0385^{* * *} \\
0.0061\end{array}$ & $\begin{array}{c}-0.0442^{* * *} \\
0.0052\end{array}$ & $\begin{array}{c}-0.0329^{* * *} \\
0.0059\end{array}$ & $\begin{array}{c}-0.0291^{* * *} \\
0.0061\end{array}$ & $\begin{array}{c}-0.0274^{* * *} \\
0.0061\end{array}$ & $\begin{array}{l}-0.0284^{* * *} \\
0.0060\end{array}$ \\
\hline Resident per capital disposable income & $\begin{array}{c}-0.0257^{* * *} \\
0.0098\end{array}$ & $\begin{array}{c}-0.0002 \\
0.0087\end{array}$ & $\begin{array}{c}-0.0394^{* * *} \\
0.0098\end{array}$ & $\begin{array}{c}0.0268^{* *} \\
0.0106\end{array}$ & $\begin{array}{c}0.0255^{* *} \\
0.0105\end{array}$ & $\begin{array}{c}0.0255^{* *} \\
0.0106\end{array}$ \\
\hline Household consumption level & $\begin{array}{c}0.0710^{* * *} \\
0.0096\end{array}$ & $\begin{array}{c}0.0561^{* * *} \\
0.0087\end{array}$ & $\begin{array}{c}0.0768^{* * *} \\
0.0098 \\
\end{array}$ & $\begin{array}{c}0.0197^{* *} \\
0.0091\end{array}$ & $\begin{array}{c}0.0194^{* *} \\
0.0090\end{array}$ & $\begin{array}{c}0.0202^{* *} \\
0.0091\end{array}$ \\
\hline $\begin{array}{l}R^{2} \\
\text { Observations } \\
\text { Per capital financial output (panel B) }\end{array}$ & $\begin{array}{c}0.8932 \\
270\end{array}$ & $\begin{array}{c}0.8875 \\
270\end{array}$ & $\begin{array}{c}0.8645 \\
270\end{array}$ & $\begin{array}{c}0.9201 \\
270\end{array}$ & $\begin{array}{c}0.9322 \\
270\end{array}$ & $\begin{array}{c}0.9343 \\
270\end{array}$ \\
\hline Intercept & $\begin{array}{c}7.4225^{* * *} \\
1.7959\end{array}$ & $\begin{array}{c}6.9715^{* * *} \\
1.4045\end{array}$ & $\begin{array}{c}5.1117^{* * *} \\
1.7200\end{array}$ & $\begin{array}{l}-9.8075^{* * *} \\
2.1683\end{array}$ & $\begin{array}{l}-7.4869^{* * *} \\
1.6563\end{array}$ & $\begin{array}{l}-9.3250^{* * *} \\
1.7146\end{array}$ \\
\hline Internet penetration rate & $\begin{array}{c}1.8474^{* * *} \\
0.3946\end{array}$ & $\begin{array}{c}0.3975^{* * *} \\
0.3837\end{array}$ & $\begin{array}{c}2.4158^{* * *} \\
0.3662\end{array}$ & $\begin{array}{l}1.7442^{* * *} \\
0.3495\end{array}$ & $\begin{array}{c}1.8052^{* * *} \\
0.3508\end{array}$ & $\begin{array}{c}1.6059^{* * *} \\
0.3255\end{array}$ \\
\hline Education level (average) & $\begin{array}{c}1.1347^{* * *} \\
0.2962\end{array}$ & - & - & $\begin{array}{l}-0.8797^{* * *} \\
0.3063\end{array}$ & - & - \\
\hline Education level (above college) & - & $\begin{array}{c}1.1976^{* * *} \\
0.1294\end{array}$ & - & - & $\begin{array}{c}-0.3539^{* * *} \\
0.1112\end{array}$ & - \\
\hline Education level (high school or above) & - & - & $\begin{array}{c}0.3850^{*} \\
0.2204\end{array}$ & - & - & $\begin{array}{l}-0.9029^{* * *} \\
0.1979\end{array}$ \\
\hline Per capital GDP & $\begin{array}{c}-0.8719^{* * *} \\
0.2583\end{array}$ & $\begin{array}{c}-0.9853^{* * *} \\
0.2178\end{array}$ & $\begin{array}{c}-0.6505^{* *} \\
0.2588\end{array}$ & $\begin{array}{l}-0.8573^{* * *} \\
0.2896\end{array}$ & $\begin{array}{l}-0.8126^{* * *} \\
0.2902\end{array}$ & $\begin{array}{c}-0.8295^{* * *} \\
0.2786\end{array}$ \\
\hline Resident per capital disposable income & $\begin{array}{l}-1.4952^{* * *} \\
0.4190\end{array}$ & $\begin{array}{c}-0.6199^{*} \\
0.3659\end{array}$ & $\begin{array}{l}-1.9383^{* * *} \\
0.4270\end{array}$ & $\begin{array}{l}2.2381^{* * *} \\
0.5056\end{array}$ & $\begin{array}{c}2.2571^{* * *} \\
0.5014\end{array}$ & $\begin{array}{c}2.1082^{* * *} \\
0.4911\end{array}$ \\
\hline Household consumption level & $\begin{array}{c}2.2649^{* * *} \\
0.4101\end{array}$ & $\begin{array}{c}1.6721^{* * *} \\
0.3664\end{array}$ & $\begin{array}{l}2.3892^{* * *} \\
0.4256\end{array}$ & $\begin{array}{c}-0.7806^{*} \\
0.4345\end{array}$ & $\begin{array}{c}-0.8772^{* *} \\
0.4309\end{array}$ & $\begin{array}{c}-0.7420^{*} \\
0.4215\end{array}$ \\
\hline$R^{2}$ & 0.9653 & 0.9443 & 0.9343 & 0.5604 & 0.6032 & 0.5843 \\
\hline Observations & 270 & 270 & 270 & 270 & 270 & 270 \\
\hline
\end{tabular}

Note. (1) ${ }^{*},{ }^{* *}$, and ${ }^{* * *}$ indicate significance at the levels of $10 \%, 5 \%$, and $1 \%$, respectively; (2) the standard error is presented below the coefficient.

for economic growth, the impact of education level, economic development level, and household consumption level on per capital financial production value was negative [54], indicating that economic development will not promote the development of the financial industry and the per capital financial output value, but also verifying that the relationship between the consumption of residents and financial investment is complementary.

Comparing the results of the mixed data model and the regional fixed model, it can be seen that the effects of disposable income and the consumption levels of residents in different regions are different, but the effect of the Internet on financial development is still significant; with an improvement in the education level, the effect of the Internet popularity rate is even more pronounced.
From the perspective of input and output, the development status of the Internet is the output of the network infrastructure investment. Therefore, on a deep level, investment in network infrastructure plays a fundamental role in promoting the development of regional finances. This paper uses the estimated value of the capital stock of the information transmission, computer service, and software industry fixed assets investment obtained in the previous sections as the capital investment of the Internet development and tests whether it has the same effect as the Internet popularization level. The results are shown in Tables 3 and 4 . According to the results of columns 1 and 2 of panels A and $\mathrm{B}$, the capital stock of network infrastructure and regional financial development have a significant negative relationship, but the impact coefficient is relatively small (0.0708 and 
$-0.0052,0.0346$ and $-0.0026 ; 1.8474$ and $-0.3889,0.3975$ and -0.2675). This shows that the investment of the national economy has a competitive relationship between the industries. The result of the mixed OLS model does not take into account the regional economic development and industry characteristics. The test results of the fixed effect model in columns 3 and 4 of panels A and B indicate that the regional Internet capital stock has a significant impact on the development of the financial industry in each region. However, it is not obvious, and its coefficient is generally small relative to the impact of Internet penetration. In general, the capital stock of infrastructure has a much smaller effect on financial development than the Internet penetration rate. Therefore, it is further explained that when considering the investment in network infrastructure, one should consider the economic conditions, technical level, and network infrastructure investments of the region to obtain the maximum utility.

\subsection{Internet Development Level and Regional Financial De-} velopment Structure. After nearly 20 years of development, the Chinese securities market has become the most active and representative market in the financial industry. As of 2012, the number of Chinese investors exceeded 100 million, and the number of Chinese investors has increased by nearly 5000 times in 20 years. The total number of accounts in the market has exceeded 150 million, so the securities market is also directly impacted by investors. Table 5 shows the impact of Internet penetration on various financial sectors. The securities transactions include the total amount of stock transactions, warrants, government bonds, futures, and other financial securities in the A-share and B-share stock markets.

The stock trading volume includes the stock trading in the Shanghai and Shenzhen stock markets. The data come from the China Securities and Futures Market Yearbook, published by the National Bureau of Statistics. The data are calculated using bidirectionally statistical calculation; the market value of stocks is by region. The market capitalization of listed companies, bank loans, bank deposits, and insurance income are all derived from the China Financial Yearbook.

Table 5 shows the impact of the Internet penetration rate (estimated by the two-way random effects model) on the number of securities transactions and the number of stock transactions. The impact of the Internet on the entire securities market is not significant, but it has a strong influence on the stock trading volume. The reason is that the trading volume of securities includes the total amount of securities, such as stocks, futures, options, treasury bonds, and funds, most of which are not securities but are generally traded by ordinary investors, so the penetration rate of the Internet has no significant impact on the total number of securities transactions. And stocks are the securities with the broadest securities group; therefore, the popularity of the Internet has a significant impact on its transaction volume. At the same time, compared with the coefficient of the control variable of the securities trading amount, the household consumption level has a significant, positive relationship with the resident stock trading and a negative relationship with the per capital disposable income; in addition, the levels of economic development and per capital disposable income have no significant impact on the stock trading quota. It is clear that the Internet has a significant impact on the daily financial behaviour of ordinary investors.

Regarding the specific content of other financial industries, because of its certain regional stability, the regional fixed effect model is adopted, and the dependent variable adopts one lag stage data. The results show that the impact coefficient of the Internet on the total production value of the major sectors of the financial industry is $1.0068(<0.001$ level), which is greater than the educational level and other economic factors. However, compared with the trading volume of the stock market, the influence of the Internet development level on the stock market value is not significant. The reason is that the popularity of the Internet plays a role in financial activities by broadening the financial participation channels of ordinary investors. The effects of other industries are not very effective over a short period of time.

4.3. Internet Development Level and Regional Investors. In order to better study the relationship between Internet development and investor participation, this paper selects two groups of samples for research. One group is the number of per capital accounts opened per year and the number of new per capital accounts opened per year, taking the proportion of accounts being opened in various places as the main indicator of financial participation; the other group is (Stock trading volume/Per capita disposable income) and (Securities transaction amount/Per capita disposable income), which indicates the number of stock transactions and the number of securities transactions contributed by the per capital disposable income of the unit.

The results in Table 6 show that, as the most representative indicator of investors participating in the stock market, the impact of the Internet on the number of new accounts per capital is more significant than the number of per capital accounts being opened, and the impact of the characteristics of other regions are also more significant than the number of new accounts per capital. The illustrated network popularity has a significant impact on the account opening situation in a year. However, the popularity of the network will have a negative impact on the stock market participation of general investors. A $1 \%$ increase in network popularity can reduce the number of new accounts opened by $1.47 \%$. Hypothesis 2 is correct. Internet penetration inhibits the financial participation of regional investors. That is, the higher the level of Internet development, the smaller the participation of investors in finance.

Table 5 shows that the popularity of the Internet has a significant impact on the total volume of securities trading and stock trading. However, the last two columns of Table 6 indicate that, from the perspective of the contribution rate of per capital disposable income, the Internet penetration rate is increased by $1 \%$, while the contribution of per capital disposable income to securities trading volume and stock 
TABLE 5: Financial business and Internet development level.

\begin{tabular}{|c|c|c|c|c|c|c|c|}
\hline \multirow[b]{2}{*}{$\begin{array}{l}\text { Financial industry } \\
\text { development }\end{array}$} & \multicolumn{2}{|c|}{ Stock market } & \multicolumn{5}{|c|}{ Other financial industries } \\
\hline & $\begin{array}{c}\text { Securities } \\
\text { transaction amount } \\
\text { Random } \\
\text { two }\end{array}$ & $\begin{array}{l}\text { Stock trading } \\
\text { volume } \\
\text { Random } \\
\text { two }\end{array}$ & $\begin{array}{c}\text { Stock market } \\
\text { value } \\
\text { Fixed } \\
\text { effects }\end{array}$ & $\begin{array}{c}\text { Bank loan } \\
\text { Fixed } \\
\text { effects }\end{array}$ & $\begin{array}{l}\text { Bank } \\
\text { savings } \\
\text { Fixed } \\
\text { effects }\end{array}$ & $\begin{array}{l}\text { Insurance } \\
\text { Fixed } \\
\text { effects }\end{array}$ & $\begin{array}{c}\text { Gross output } \\
\text { value } \\
\text { Fixed } \\
\text { effects }\end{array}$ \\
\hline \multirow{2}{*}{ Intercept } & 3.0695 & $12.4553^{* * *}$ & -2.0268 & $4.3139^{* * *}$ & 1.4567 & $-4.1735^{* * *}$ & 2.1978 \\
\hline & 3.0951 & 2.3480 & 4.3409 & 0.7632 & 1.3703 & 0.9313 & 1.6412 \\
\hline \multirow{2}{*}{ Internet penetration rate } & 0.0803 & $0.6074^{* * *}$ & 0.8466 & $0.9769^{* * *}$ & $0.7468^{* * *}$ & $0.5345^{* * *}$ & $1.0068^{* * *}$ \\
\hline & 0.3388 & 0.2273 & 0.7302 & 0.1284 & 0.2305 & 0.1567 & 0.2761 \\
\hline \multirow{2}{*}{ Education level (average) } & $0.6678^{* * *}$ & $0.5177^{* * *}$ & $1.3936^{* *}$ & $0.3926^{* * *}$ & 0.2247 & $0.2741^{* *}$ & $0.4893^{* *}$ \\
\hline & 0.2364 & 0.1556 & 0.5772 & 0.1015 & 0.1822 & 0.1238 & 0.2183 \\
\hline \multirow{2}{*}{ Per capital GDP } & $0.4828^{* *}$ & 0.1384 & 0.9055 & $0.2099^{* *}$ & $0.4597^{* *}$ & $0.6815^{* * *}$ & 0.2971 \\
\hline & 0.2289 & 0.1515 & 0.5662 & 0.0995 & 0.1787 & 0.1215 & 0.2141 \\
\hline Resident per capital & $0.9134^{* *}$ & -0.1819 & $2.4646^{* *}$ & -0.1646 & 0.1207 & $0.5220^{* *}$ & $0.7495^{*}$ \\
\hline disposable income & 0.4539 & 0.3100 & 1.0343 & 0.1819 & 0.3265 & 0.2219 & 0.3910 \\
\hline Household consumption & 0.5110 & $0.8745^{* * *}$ & $-1.8895^{* *}$ & $0.7103^{* * *}$ & 0.3886 & -0.0932 & -0.0617 \\
\hline level & 0.3565 & 0.2400 & 0.8802 & 0.1548 & 0.2778 & 0.1888 & 0.3328 \\
\hline$\overline{R^{2}}$ & 0.2434 & 0.1859 & 0.8781 & 0.9926 & 0.9790 & 0.9916 & 0.9710 \\
\hline Observations & 270 & 270 & 270 & 270 & 270 & 270 & 270 \\
\hline
\end{tabular}

Note, $(1){ }^{*}, * *$, and ${ }^{* * *}$ represent significance at the levels of $10 \%, 5 \%$, and $1 \%$, respectively; (2) the standard error is presented below the coefficient.

TABle 6: The degree of participation in the securities market and the level of Internet development.

\begin{tabular}{|c|c|c|c|c|}
\hline \multirow{2}{*}{$\begin{array}{l}\text { Stock market participation } \\
\text { willingness }\end{array}$} & $\begin{array}{l}\text { Per capital account } \\
\text { opening }\end{array}$ & $\begin{array}{l}\text { Number of new } \\
\text { accounts per capital }\end{array}$ & $\begin{array}{l}\text { Securities trading volume/ } \\
\text { per capital disposable income }\end{array}$ & $\begin{array}{l}\text { Stock trading volume/ } \\
\text { per capital disposable } \\
\text { income }\end{array}$ \\
\hline & $\begin{array}{c}\text { Fixed } \\
\text { Regional effect }\end{array}$ & $\begin{array}{c}\text { Fixed } \\
\text { Regional effect }\end{array}$ & Random two & Random two \\
\hline \multirow{2}{*}{ Intercept } & $-3.4511^{*}$ & -1.3004 & 1.6971 & $4.4866^{* * *}$ \\
\hline & 2.0329 & 3.0475 & 1.3694 & 1.1683 \\
\hline \multirow{2}{*}{ Internet penetration rate } & $-0.7267^{* *}$ & $-1.4707^{* * *}$ & $-0.4345^{* *}$ & $-0.1520^{* *}$ \\
\hline & 0.3116 & 0.4671 & 0.2100 & 0.0760 \\
\hline \multirow{2}{*}{ Education level (average) } & 0.0832 & $1.6813^{* * *}$ & $0.8162^{* * *}$ & $0.6355^{* * *}$ \\
\hline & 0.2509 & 0.3761 & 0.1839 & 0.1790 \\
\hline \multirow{2}{*}{ Per capital GDP } & $1.0243^{* * *}$ & $1.3385^{* * *}$ & $-0.3236^{* *}$ & -0.19053 \\
\hline & 0.2306 & 0.3457 & 0.1549 & 0.1361 \\
\hline \multirow{2}{*}{ Per capital disposable income } & 0.6551 & $-1.7969^{* * *}$ & - & - \\
\hline & 0.4444 & 0.6661 & & \\
\hline \multirow{2}{*}{ Per capital property holding level } & - & - & -0.4345 & -0.3655 \\
\hline & & & 0.2344 & 0.2443 \\
\hline \multirow{2}{*}{ Household consumption level } & $-0.6267^{*}$ & 0.6440 & $-0.4480^{* *}$ & $-0.78902^{* * *}$ \\
\hline & 0.3767 & 0.5647 & 0.2095 & 0.1652 \\
\hline$R^{2}$ & 0.9596 & 0.9061 & 0.1053 & 0.1298 \\
\hline Observations & 232 & 232 & 232 & 232 \\
\hline
\end{tabular}

Note. $(1)^{*},{ }^{* *}$, and ${ }^{* * *}$ represent significance at levels of $10 \%, 5 \%$, and $1 \%$, respectively; (2) the standard error is presented below the coefficient.

trading volume decreased by $0.43 \%$ and $0.15 \%$, respectively; in addition, the level of economic development, property holdings, and household consumption levels also had a negative impact. This shows that the more common the use of the Internet is and the higher the economic development level and the consumption level of residents are, the more the investors are reluctant to participate in the stock market. From the perspective of economic information dissemination, economic development has broadened investment channels, and the popularity of the network has improved the asymmetry of information; therefore, investors are no longer the only ones involved in investment in the securities market. In addition, consistent with Wang and Tian [55], education levels and property holdings have a negative impact on participation in the securities market, but the impact of property holdings is not significant.

4.4. Robustness Test. In order to further test the reliability of the Internet penetration rate, this paper conducts a robustness test. Lin et al. [56], Xianming et al. [57], and Wenqing et al. [58] all pointed out that the development of the financial industry at a provincial level has a spatially dependent effect. From the perspective of network transmission technology, the communication capability of each node of the Internet is determined not only by itself, but also 
TABLE 7: Robustness test based on the spatial econometric model.

\begin{tabular}{|c|c|c|c|c|c|}
\hline Robustness test & $\begin{array}{l}\text { Financial } \\
\text { industry }\end{array}$ & $\begin{array}{l}\text { Per capital financial } \\
\text { output }\end{array}$ & $\begin{array}{l}\text { Per capital account } \\
\text { opening }\end{array}$ & $\begin{array}{l}\text { Securities trading/per } \\
\text { capital disposable income }\end{array}$ & $\begin{array}{l}\text { Stock trading volume/ } \\
\text { per capital disposable } \\
\text { income }\end{array}$ \\
\hline \multirow{2}{*}{ Intercept } & 0.0217 & $-5.1793^{* *}$ & $7.5696^{* * *}$ & $-36.9791^{* * *}$ & $24.9292^{*}$ \\
\hline & 0.0402 & 2.0890 & 1.8449 & 4.2087 & 14.1119 \\
\hline \multirow{2}{*}{$\begin{array}{l}\text { Internet penetration in } \\
\text { neighboring provinces }\end{array}$} & $0.0363^{* * *}$ & $1.3026^{* * *}$ & $-2.4712^{* * *}$ & $-3.8923^{* *}$ & $-2.8614^{* * *}$ \\
\hline & 0.0041 & 0.2118 & 0.6679 & 1.5236 & 0.9044 \\
\hline \multirow{2}{*}{ Education level (average) } & -0.0075 & $-0.6679^{* *}$ & $0.7729^{* * *}$ & $1.3074^{* * *}$ & $2.1835^{* * *}$ \\
\hline & 0.0051 & 0.2640 & 0.2135 & 0.4872 & 0.7544 \\
\hline \multirow[t]{2}{*}{ Per capital GDP } & $\overline{-}^{-}+0242^{* * *}$ & $-0.8442^{* * *}$ & -0.2473 & $-0.7723^{* *}$ & $2.7930^{* * *}$ \\
\hline & 0.0050 & 0.2588 & 0.1635 & 0.3729 & 0.7510 \\
\hline \multirow{2}{*}{$\begin{array}{l}\text { Per capital disposable } \\
\text { income }\end{array}$} & $0.0200^{* *}$ & $2.0762^{* * *}$ & $-1.8382^{* * *}$ & - & - \\
\hline & 0.0092 & 0.4774 & 0.4105 & & \\
\hline \multirow{4}{*}{$\begin{array}{l}\text { Per capital property holding } \\
\text { level } \\
\text { Household consumption } \\
\text { level }\end{array}$} & - & - & - & $4.0885^{*}$ & $-6.0615^{*}$ \\
\hline & & & & 0.9365 & 1.5541 \\
\hline & 0.0037 & $-1.0500^{* * *}$ & $2.3904^{* * *}$ & 0.1964 & $2.2876^{*}$ \\
\hline & 0.0077 & 0.4013 & 0.3063 & 0.6987 & 1.2026 \\
\hline$\overline{R^{2}}$ & 0.9709 & 0.9830 & 0.8503 & 0.5155 & 0.9315 \\
\hline Observations & 270 & 270 & 232 & 232 & 270 \\
\hline
\end{tabular}

Note. $(1)^{*}, * *$, and ${ }^{* * *}$ represent significance at the levels of $10 \%, 5 \%$, and $1 \%$, respectively; (2) the standard error is presented below the coefficient.

by the communication capabilities of the entire network (Yuan and Li ) [59]. At the same time, due to the popularity of the network brought about by the advancement of network technology, agglomeration effects can also occur across the network, and the level of communication in the network infrastructure is usually determined by the level of network infrastructure in the adjacent area. According to the model of spatial measurement, the penetration rate of neighboring provinces is calculated. Different from the economic indicators with a spillover nature, the Internet penetration rate of neighboring provinces is mainly determined by factors such as the province's own input and output. However, the network penetration rate of each province is partly reflected by the networks of neighboring provinces. Therefore, the neighboring network penetration rate is used as a robustness test. The adjacency relationship set up in equation (6) is used as the weight matrix of the provincial network penetration rate, where $\mathrm{W}_{\mathrm{i}}$ is the weight matrix:

$$
Y_{i, t}=\alpha_{i}+W_{i} X_{i, t}+X_{\text {contr }, t}+\varepsilon_{i, t} .
$$

This paper selected some dependent variables and used the same estimation method as the previous one to test the robustness. The results are shown in Table 7. The influence of Internet penetration rate in neighboring provinces on the stock market participation of the financial industry and investors is generally significant. The relationship is consistent with the direction of Internet penetration in the provinces.

\section{Conclusions and Recommendations}

In this paper, the input and output data of network infrastructure and panel data of financial industry are used to analyze the input and output efficiency of network infrastructure and the influence of the Internet on the financial industry (the production value of the financial industry, various fields of the financial industry, and the financial participation of investors). This paper focuses on the impact of Internet investment efficiency and the Internet penetration rate of each province on the financial industry and finds that there is a significant difference between the Internet investment efficiency and the level of network development in each province. The popularization of the Internet can significantly improve the total output value and per capita output value of the financial industry. However, the popularity of the Internet will reduce the participation of investors in the securities market. The reason is that the popularity of the Internet provides a wide range of information channels for most investors, thus reducing the degree of information asymmetry. On the other hand, the development of the Internet provides investors with a more convenient platform, so it is easier for investors to access other areas of the financial industry.

The analysis of the above results shows that because of the different levels of economic development, the difference in consumption levels, and the income of residents, the starting point of network infrastructure construction is different, and the capital and technology that can be invested are different. However, by introducing advanced technologies in developed regions, with limited investment, areas that are more backward in terms of information and communication technologies can catch up with the informatization level of developed regions and directly realize leap-forward development; the advent of the Internet era has had a profound impact on the financial industry, achieved through the financial behaviour of investors and hundreds of millions of netizens. The demand of consumer groups and small and medium-sized investors has given rise to the impact of the "Internet finance" model of different forms on the traditional financial services industry. Therefore, the conclusions of this paper have significance for the integration of the traditional financial 
industry, the networking of finance, and the development of Internet finance.

At present, network technologies represented by emerging technologies such as the Internet of things, cloud computing, social networks, and mobile payment have had huge impacts on the whole economy. Internet penetration, oriented to consumption preferences, may has the most significant impact on economic fluctuations. Therefore, the effect of the Internet on economic growth and the change in consumption modes caused by it are not considered in this paper, so these are potential further research directions.

\section{Data Availability}

The data used to support the findings of this study are available from the corresponding author upon request.

\section{Conflicts of Interest}

The authors declare no conflicts of interest.

\section{Acknowledgments}

This research was funded by the Social Science Foundation of Fujian Province (FJ2018B062 and FJ2019B101); the Xiamen Science and Technology Plan Project (2018S2247); and Fujian Provincial Department of Science and Technology-Soft Science Research Plan Project (2019R0093 and 2019R0094).

\section{References}

[1] B. Zhu, S. Zhai, and J. He, "Is the development of China's financial inclusion sustainable? Evidence from a perspective of balance," Sustainability, vol. 10, no. 1200, 2018.

[2] C. Elgin, "Internet usage and the shadow economy: evidence from panel data," Economic Systems, vol. 37, no. 1, pp. 111-121, 2013.

[3] S. Sassi and M. Goaied, "Financial development, ICT diffusion and economic growth: lessons from MENA region," Telecommunications Policy, vol. 37, no. 4-5, pp. 252-261, 2013.

[4] H. Kim, E. Kang, E. A. Lee, and D. Broman, "A toolkit for construction of authorization service infrastructure for the internet of things," in Proceedings of the 2nd ACM/IEEE International Conference on Internet-of-Things Design and Implementation, vol. 3, p. 12, Pittsburgh, PA USA, April 2017.

[5] G. E. Moore, "Cramming more components onto integrated circuits, Reprinted from Electronics," IEEE Solid-State Circuits Society Newsletter, vol. 11, pp. 33-35, 2006.

[6] L. Zijun and C. Wenjun, "An empirical study on the relationship between internet development level and economic growth in China," Economic Geography, vol. 37, no. 8, pp. 108-113, 2017.

[7] S. Aithal, P. K. Paul, A. Bhuimali et al., Emerging Internet Services Vis-à-Vis Development: A Theoretical Overview, Social Science Electronic Publishing, Rochester, NY, USA, 2017.

[8] J. A. Schumpeter, "The creative response in economic history," The Journal of Economic History, vol. 7, no. 2, pp. 149-159, 1947.

[9] R. E. Lucas, "On the mechanics of economic development," Journal of Monetary Economics, vol. 22, no. 1, pp. 3-42, 1988.
[10] P. Spilling, “The Internet Development Process: Observations and Reflections," in Procedings of the History of Nordic Computing 3-Third IFIP WG 9.7 Conference, HiNC, vol. 3, Stockholm, Sweden, October 2010.

[11] Ü1 Seven and H. Yetkiner, "Financial intermediation and economic growth: does income matter?" Economic Systems, vol. 40, no. 1, pp. 39-58, 2016.

[12] G. M. Caporale, P. G. Howells, and A. M. Soliman, "Stock market development and economic growth: the causal linkage," Journal of Economic Development, vol. 29, pp. 33-50, 2004.

[13] R. P. Pradhan, M. B. Arvin, N. R. Norman, and S. K. Bele, "Economic growth and the development of telecommunications infrastructure in the G-20 countries: a panel-VAR approach," Telecommunications Policy, vol. 38, no. 7, pp. 634-649, 2014.

[14] M. E. Batuo, "The role of telecommunications infrastructure in the regional economic growth of Africa," The Journal of Developing Areas, vol. 49, no. 1, pp. 313-330, 2015.

[15] R. Levine, "Financial development and economic growth: views and agenda," Journal of Economic Literature, vol. 35, pp. 688-726, 1997.

[16] K. D. Frazer, NSFNET:A Partnership for High-Speed Networking, Merit Network, Ann Arbor, MI, USA, 1996.

[17] Z. Chen, Y. Li, Y. Wu, and J. Luo, "The transition from traditional banking to mobile internet finance: an organizational innovation perspective-a comparative study of Citibank and ICBC," Financial Innovation, vol. 3, no. 12, 2017.

[18] X. Hou, Z. Gao, and Q. Wang, "Internet finance development and banking market discipline: evidence from China," Journal of Financial Stability, vol. 22, pp. 88-100, 2016.

[19] X. Chang and S. Deng, "The development of supply chain finance in China," International Journal of Management Excellence, vol. 3, no. 3, pp. 475-479, 2014.

[20] K. Wang, S. Tsai, X. Du, and D. Bi, "Internet finance, green finance, and sustainability," Multidisciplinary Digital Publishing Institute, 2019.

[21] K. Liao, M. Yue, S. Sun et al., "An evaluation of coupling coordination between tourism and finance," SustainabilityBasel, vol. 102320 pages, 2018.

[22] S. Dowrick and M. Rogers, "Classical and technological convergence: beyond the Solow-Swan growth model," Oxford Economic Papers, vol. 54, no. 3, pp. 369-385, 2002.

[23] H. Priemus, "The network approach: Dutch spatial planning between substratum and infrastructure networks," European Planning Studies, vol. 15, no. 5, pp. 667-686, 2007.

[24] K. M. Vu, "ICT as a source of economic growth in the information age: empirical evidence from the 1996-2005 period," Telecommunications Policy, vol. 35, no. 4, pp. 357-372, 2011.

[25] R. P. Pradhan, G. Mallik, and T. P. Bagchi, "Information communication technology (ICT) infrastructure and economic growth: a causality evinced by cross-country panel data," IIMB Management Review, vol. 30, no. 1, pp. 91-103, 2018.

[26] A. O. Binuyo and R. A. Aregbeshola, "The impact of information and communication technology (ICT) on commercial bank performance: evidence from South Africa," Problems and Perspectives in Management, vol. 12, pp. 59-68, 2014.

[27] E. Tranos, "The causal effect of the internet infrastructure on the economic development of European city regions," Spatial Economic Analysis, vol. 7, no. 3, pp. 319-337, 2012.

[28] R. P. Pradhan, M. B. Arvin, and N. R. Norman, "The dynamics of information and communications technologies infrastructure, economic growth, and financial development: 
evidence from Asian countries," Technology in Society, vol. 42, pp. 135-149, 2015.

[29] N. Czernich, O. Falck, T. Kretschmer, and L. Woessmann, "Broadband infrastructure and economic growth," The Economic Journal, vol. 121, no. 552, pp. 505-532, 2011.

[30] A. Heshmati and W. Yang, "Contribution of ICT to the Chinese economic growth," Ratio Working Papers, vol. 91, 2006.

[31] S. L. Liu and A. G. Hu, "Test on the externality of infrastructure in China: 1988-2007," Economic Research Journal, vol. 3, pp. 4-15, 2010.

[32] L. I. Li-wei and J. Feng, "Relationship between internet diffusion and economic growth: empirical research based on panel data of China's 31 provinces," Journal of Beijing Technology and Business University (Social Sciences), vol. 28, pp. 120-126, 2013.

[33] Y. Z. Luo, M. J. Rui, L. J. Luo, and S. L. Zhu, "Telecommunications investment: infrastructure, network effect and regional disequilibrium," Economic Research Journal, vol. 6, pp. 61-72, 2008.

[34] H. Zhong, W. Zi-dong, C. Xia, and L. Ting-jie, "Impact of broadband on China's economic growth," Journal of Beijing University of Posts and Telecommunications (Social Sciences Edition), vol. 15, pp. 82-86, 2013.

[35] C. Sharon, "COBB, "redefining "offshore" in Latin America", " Growth and Change, vol. 40, no. 2, pp. 332-356, 2009.

[36] H. Hong, J. D. Kubik, and J. C. Stein, "Social interaction and stock-market participation," The Journal of Finance, vol. 59, no. 1, pp. 137-163, 2004.

[37] D. Georgarakos and G. Pasini, "Trust, sociability, and stock market participation*," Review of Finance, vol. 15, no. 4, pp. 693-725, 2011.

[38] C. Choi, D.-E. Rhee, and Y. Oh, "Information and capital flows revisited: the Internet as a determinant of transactions in financial assets," Economic Modelling, vol. 40, pp. 191-198, 2014.

[39] C. Wang and C. Tian, "Stock market participation, participation rate and determinants," Economic Research Journal, vol. 10, pp. 97-107, 2012.

[40] P. Aghion and P. Howitt, "Endogenous Growth Theory," MIT Press, Cambridge, MA, 1998.

[41] J. Benhabib and M. Spiegel, "Human capital and technology diffusion," 2005.

[42] D. W. Jorgenson, M. S. Ho, and K. J. Stiroh, "A retrospective look at the U.S. Productivity growth resurgence," Journal of Economic Perspectives, vol. 22, no. 1, pp. 3-24, 2008.

[43] M. H. Yi and C. Choi, "The effect of the internet on inflation: panel data evidence," Journal of Policy Modeling, vol. 27, no. 7, pp. 885-889, 2005.

[44] Y.-H. Noh and K. Yoo, "Internet, inequality and growth," Journal of Policy Modeling, vol. 30, no. 6, pp. 1005-1016, 2008.

[45] Y. F. Justin, L. X. Lin, and X. Colin, "Some Recent Progresses on Financial Structure and Development," Palgrave Macmillan UK, London. UK, 2012.

[46] F. Allen, "Financial Structure," Economic Growth and Development, Washington, DC, USA, 2018.

[47] T. T. T. Le and J. T. L. Ooi, "Financial structure of property companies and capital market development," Journal of Property Investment \& Finance, vol. 30, no. 6, pp. 596-611, 2012.

[48] G. C. Liu, Y. Y. Liu, and C. S. Zhang, "Financial Development, Financial Structure and Income Inequality in China," World Economy, vol. 40, no. 9, 2017.
[49] J. Zhang, G. Y. Wu, and J. P. Zhang, "The estimation of China's provincial capital stock: 1952-2000," Economic Research Journal, vol. 10, pp. 35-44, 2004.

[50] G. Jin, "The estimation of China's infrastructure capital stock," Economic Research Journal, vol. 47, pp. 4-14, 2012.

[51] R. W. Goldsmith, "Financial structure and development as a subject for international comparative study," Journal of Infection \& Chemotherapy Official Journal of the Japan Society of Chemotherapy, vol. 20, no. 3, pp. 143-145, 1959.

[52] R. G. King and R. Levine, "Finance and growth: Schumpeter might be right," The Quarterly Journal of Economics, vol. 108, no. 3, pp. 717-737, 1993.

[53] M. L. Cheng and Y. Han, "A modified Cobb-Douglas production function model and its application," IMA Journal of Management Mathematics, vol. 25, no. 3, pp. 353-365, 2013.

[54] R. Y. Tan, "An empirical study of the relationship between China's financial development and economic growth," Economic Research Journal, vol. 10, pp. 53-61, 1999.

[55] C. Wang and C. Z. Tian, "Stock market participation, participation rate and determinants," Economic Research Journal, vol. 10, pp. 97-107, 2012.

[56] Y. F. Lin, Z. Qi, and M. X. Liu, "Financial structure and economic growth: the case of manufacturing industry," China Finance, vol. 1, pp. 3-21, 2003.

[57] M. Fang, A. J. Sun, and Y. F. Cao, "Research on financial support and economic growth based on spatial model: evidence from Chinese provinces, 1998-2008," Journal of Finance Research, vol. 10, pp. 68-82, 2010.

[58] W. Q. Pan, Z. N. Li, and Q. Liu, "Inter-industry technology spillover effects in China: evidence from 35 industry sectors," Economic Research Journal, vol. 46, pp. 18-29, 2011.

[59] X. L. Yuan and S. P. Li, "Multimedia data flow transmission technology research in the network," in Proceedings of the 8th International Conference on Intelligent Computation Technology and Automation (ICICTA), IEEE, Nanchang, China, June 2015. 